NIST Special Publication 1211

\title{
Risk Assessment of Brucellosis for Tissues Processed and Archived at the Marine Environmental Specimen Bank
}

Jennifer M. Ness

Amanda J. Moors

Rebecca S. Pugh

This publication is available free of charge from:

https://doi.org/10.6028/NIST.SP.1211

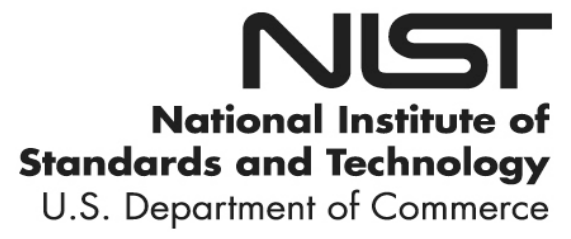


NIST Special Publication 1211

\title{
Risk Assessment of Brucellosis for Tissues Processed and Archived at the Marine Environmental Specimen Bank
}

\author{
Jennifer M. Ness \\ Amanda J. Moors \\ Rebecca S. Pugh \\ Chemical Sciences Division \\ Material Measurement Laboratory
}

This publication is available free of charge from:

https://doi.org/10.6028/NIST.SP.1211

March 2017

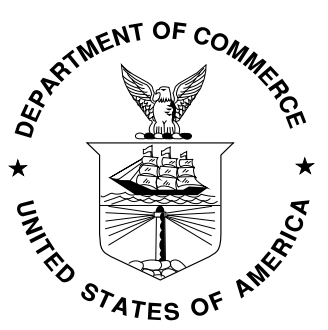

U.S. Department of Commerce Wilbur L. Ross, Jr., Secretary

National Institute of Standards and Technology Kent Rochford, Acting NIST Director and Under Secretary of Commerce for Standards and Technology 
Certain commercial entities, equipment, or materials may be identified in this document in order to describe an experimental procedure or concept adequately. Such identification is not intended to imply recommendation or endorsement by the National Institute of Standards and Technology, nor is it intended to imply that the entities, materials, or equipment are necessarily the best available for the purpose.

National Institute of Standards and Technology Special Publication 1211 Natl. Inst. Stand. Technol. Spec. Publ. 1211, 25 pages (March 2017)

This publication is available free of charge from: https://doi.org/10.6028/NIST.SP.1211 


\section{Table of Contents}

1 NIST Marine Environmental Specimen Bank (Marine ESB) ................................. 1

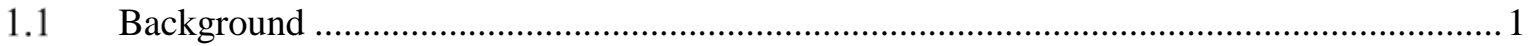

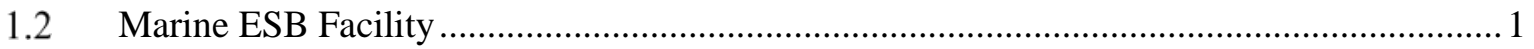

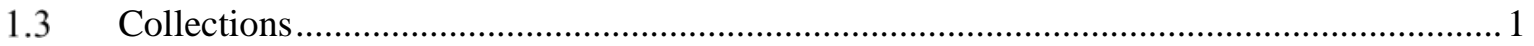

1.3.1 Northern Gulf of Mexico Cetacean Unusual Mortality Event......................................... 1

1.3.2 National Marine Mammal Tissue Bank............................................................................. 2

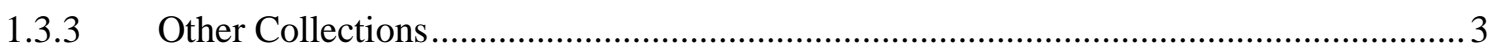

2 Risk Assessment ............................................................................................................. 3

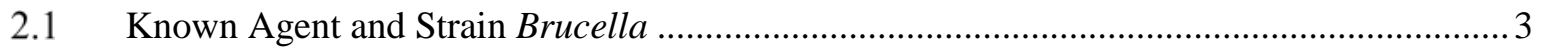

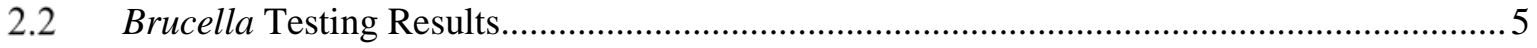

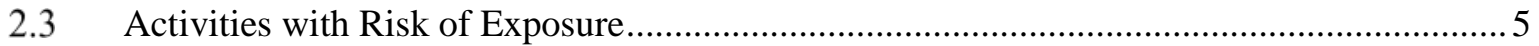

2.3.1 Receiving and Shipping Samples ….......................................................................... 5

2.3.2 Collection and Processing of Samples for NMMTB .................................................... 9

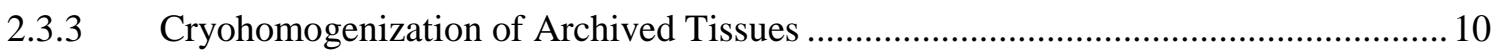

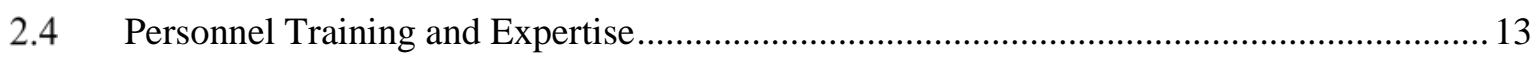

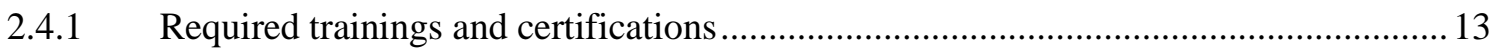

2.4.2 Responsible Parties and Authorized Personnel ........................................................... 13

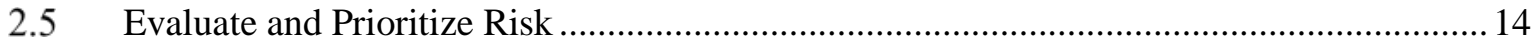

$2.6 \quad$ Develop or evaluate controls to mitigate exposure …....................................................... 14

3 Emergency Procedures....................................................................................................... 16

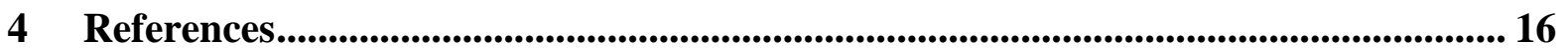

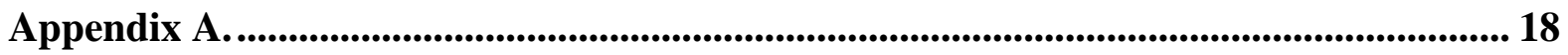




\section{$1 \quad$ NIST Marine Environmental Specimen Bank (Marine ESB)}

\section{$1.1 \quad$ Background}

The National Institute of Standards and Technology (NIST) has been involved in environmental specimen banking since 1979 through collaborations with various research and monitoring programs. Samples from on-going marine related projects are collected and archived at ultra-cold and cryogenic temperatures $\left(-80 \mathrm{C}^{\circ}\right.$ and $\left.-150^{\circ} \mathrm{C}\right)$ in NIST's Marine Environmental Specimen Bank (Marine ESB), Hollings Marine Laboratory (HML), Charleston, SC. These samples include: sediments, mussels, oysters, marine mammal tissues and fluids, bird egg contents and feathers, sea turtle tissues and fluids, coral tissue, coralline algae, and fish tissues.

\subsection{Marine ESB Facility}

The Marine ESB was designed and operates under ISO Certified Class 5, 6 and 7 clean room conditions. Stored samples are brought into the bank facility through an ISO Class 6 anteroom and are stored in liquid nitrogen vapor-phase and ultra-cold electric freezers in the ISO Class 7 Freezer Room, Room D104. These clean air laboratories control the concentration of airborne particles to specified limits and are essential in minimizing contamination of samples during processing. In addition, the Marine ESB is a secure area with key-card access restricted to trained Marine ESB personnel or other trained researchers who are escorted by Marine ESB personnel. Personal protective equipment (PPE) is required at all times when entering and working in the Marine ESB. PPE includes disposable Tyvek coverall (full body), open-faced hood and mask or eyes-only hood, boot covers, safety glasses, and gloves (general laboratory vinyl gloves and/or cryogenic gloves). The work activities and required PPE for the Marine ESB are listed in the Job Hazard Analysis Forms which are approved and signed by all Marine ESB personnel, the NIST Supervisor, and the Area Safety Representative for the HML as well as the NIST Hazard Review System which are approved by the Group Leaders, Division Chief, and Lab Directors, when necessary. Environmental conditions in the laboratory (humidity, temperature, and oxygen levels) and freezer temperatures are monitored 24/7 using a monitoring system (1).

\subsection{Collections}

\subsubsection{Northern Gulf of Mexico Cetacean Unusual Mortality Event}

NIST has been indirectly involved in the response to the 2010 Deep Water Horizon Gulf of Mexico Oil Spill incident. In support of the National Oceanic and Atmospheric Administration, National Marine Fisheries Service, Office of Protected Resources (NOAA/NMFS/OPR), NIST has become the lead repository for frozen marine mammal (primarily bottlenose dolphin, Tursiops truncatus) samples collected in response to this event. Sources of these samples are: stranding events (including the ongoing Northern Gulf of Mexico Cetacean Unusual Mortality Event), live capture health assessments, and dart biopsy collections 
conducted throughout the Gulf of Mexico region. Since May 2010, NIST has received thousands of tissue samples (no microbial cultures) that were collected in the field and shipped frozen to the Marine ESB for storage following strict Chain of Custody guidelines. The majority of the frozen samples received have come from strandings as a part of the Northern Gulf of Mexico Cetacean Unusual Mortality Event. These samples were collected and shipped from marine mammal stranding network participants, including the Institute for Marine Mammal Studies (IMMS), Gulf World Marine Park, the Emerald Coast Wildlife Refuge (ECWR), NOAA Southeast Fisheries Science Center, Dauphin Island Sea Lab (DISL), and the Audubon Aquatic Institute.

Samples maintained at the Marine ESB are requested by NMFS/OPR to be sent to various laboratories for testing and analyses, including testing for zoonotic pathogens, such as Brucella and Morbillivirus and analyses for polycyclic aromatic hydrocarbons (PAH's) and biotoxins.

In October 2011, NIST Marine ESB personnel were informed by NMFS/OPR that samples shipped out for testing in July, August, and October of 2011 tested positive for marine Brucella, the causal agent of brucellosis. A total of 33 frozen tissue samples, including lung, spleen, kidney, umbilicus, cerebrospinal fluid, placenta and lung lymph node, were shipped from the Marine ESB to Michael Kinsel at the University of Illinois, Zoological Pathology Program, in Maywood, IL for Brucella testing. Since 2011 more samples have tested positive for marine Brucella. Additional samples maintained at the Marine ESB are currently being requested to be shipped for marine Brucella testing as well as more testing in the future. According to a recent study the prevalence of Brucella and Morbillivirus infections, which were investigated as potential alternative causes for increased dolphin deaths, was low in UME dolphins after the oil spill and was no different compared to reference dolphin populations (2).

\subsubsection{National Marine Mammal Tissue Bank}

The National Marine Mammal Tissue Bank (NMMTB) consists of two ongoing environmental monitoring projects, the Alaska Marine Mammal Tissue Archival Project (AMMTAP), established in 1987 and the Marine Mammal Health and Stranding Response Program (MMHSRP), established in 1990. These projects provide a large percentage of samples banked at the Marine ESB. The NMMTB was formally established by the Marine Mammal Health and Stranding Response Act (Public Law 102-587) and expanded to become a larger program that resulted in several components; the Marine Mammal Stranding Networks, the NMMTB, and a Monitoring and Quality Assurance Program. The MMHSRP is focused on animal health assessment, real-time contaminant monitoring, specimen banking, response to strandings and mass mortalities, quality assurance/quality control of analytical results, and the management of a nationwide database on the health of marine mammal populations. NIST currently maintains the NMMTB and the Monitoring and Quality Assurance Program. The NMMTB houses liver, kidney, 
blubber/adipose, muscle, and brain tissues from stranded animals which include cetaceans, pinnipeds, and polar bears (3).

\subsubsection{Other Collections}

Tissue collections from other projects are obtained from healthy animals or animals that are not suspected to be infectious. These include sea bird egg contents, marine mammal tissues taken from Alaskan subsistence harvested animals, marine mammal tissues taken from incidental takes, marine mammal fluids taken from human managed animals, bivalves, sport fish tissue, sea turtle tissues and fluids, sea turtle egg contents, and specimens from live captured cetaceans. These samples pose little zoonotic risk when handled with required PPE.

\section{Risk Assessment}

\subsection{Known Agent and Strain Brucella}

Marine mammal isolates of the genus Brucella (Brucella pinnipedialis and Brucella ceti, sometimes referred to as Brucella maris) are potentially zoonotic, causing the disease Brucellosis. However, the frequency of transmission to humans is unknown. There have been a total of four confirmed human infections of marine Brucella. Three of these infections are naturally occurring thought to have been caused by the consumption of raw fish (4), (5) since none of the patients had any contact with marine mammals. The fourth, a laboratory acquired infection, was mild and presented no complications (6). Marine mammal isolates of Brucella are not considered select agents by the Centers for Disease Control and Prevention (CDC) and the United States Department of Agriculture/Animal and Plant Health Inspection Service (APHIS) (7).

Brucella is gram negative coccobacilli. Brucella species are thought to be stable in the environment in carcasses and organs up to 135 days, and up to 180 days in blood stored at $4^{\circ} \mathrm{C}$. With regards to terrestrial Brucella, laboratory infections typically occur when the bacteria is grown in large cultures. Routes of exposure can include ingestion, direct contact with skin abrasions and mucous membranes, as well as inhalation of the aerosolized agent. Reservoirs of infectious agent include infected tissues, blood, urine, vaginal discharge, and aborted fetuses $(8,9)$. Routes of exposure are poorly understood in marine Brucella, with little evidence to support any route of infection. Infectious doses of terrestrial Brucella species are as little as 10 to 100 organisms $(10,11)$ and the incubation period for terrestrial Brucella can run from 1 to 15 weeks. The infectious dose and incubation period of marine Brucella is not known. Infections can be symptomatic or asymptomatic. When symptoms are present the disease is extremely variable and clinical signs may appear abruptly or insidiously. The disease typically begins with nonspecific flu-like signs such as fever, headache, back pain, malaise and generalized aches. Some patients will recover spontaneously while others develop persistent symptoms that wax and wane. Occasionally additional complications arise including, arthritis, spondylitis, chronic fatigue, anemia, internal abscesses, nephritis, endocarditis and dermatitis. 
Neurological signs occur in less than $5 \%$ of patients but can include personality changes, meningitis, uveitis and optic neuritis (9).

There is no vaccine for brucellosis. Minimizing exposure risk is the best prophylaxis. If an infection does occur, antibiotics like tetracycline can be administered for at least six weeks. The bacteria are typically resistant to penicillin and cephalosporin. Special antibiotics may need to be used in pregnant women; cotrimoxazole has been used with reported success. Since the bacteria do not form spores, they can be easily destroyed using standard disinfectants, (70\% alcohol and $1 \%$ sodium hypochlorite sprays) (8).

NMFS NOAA has issued Brucella specific biosafety guidelines for stranding network personnel when handling cetaceans or pinnipeds that are suspected of being infected with Brucella. The guidelines name the following animals as being "High-Risk" animals and recommend minimum levels of PPE for necropsies from animals suspected of Brucella infections.

NOAA/NMFS Interim Marine Mammal Brucella specific Biosafety Guidelines for the National Marine Mammal Stranding Network

a.) High Risk Animals for Suspect Brucella infections

- Cetaceans: All Species (Pregnant Females, Neonates, Juveniles, SubAdults, Adults with skin or bony lesions)

- Pinnipeds: All Species (Pregnant Females), Harbor Seals (Pups, Yearlings and Sub-Adults)

b.) Minimum PPE recommendations for Necropsy (field or laboratory)

- Tyvek suit, gloves, face shields (field necropsies). Additional PPE for procedures that create aerosols, standard PPE plus NIOSH-certified N-95 respirator.

CDC Guidelines for Safe Work Practice in Animal Diagnostic Laboratories

a.) PPE for Necropsy Personnel

- Fluid-resistant clothing, gloves (double gloving), cut-resistant glove

- Protection from splashes and aerosols (when risk assessment indicates a high likelihood for zoonotic agents) use transparent face shield (covering eyes mouth and neck) and an NIOSH-certified N-95 respirator.

b.) Disinfection

- Surfaces and floors should be washed with detergent and then disinfected with a 1:10 bleach solution or alcohol. 
- Sharp objects placed in puncture resistant containers and washed with detergent solution rinsed and wet with disinfectant or autoclaved.

- Disposable items discarded into a biohazard container for terminal treatment or autoclaving.

- No dirty items or anything used in necropsy removed from room without disinfection and wash hands at end of all activities.

- Waste management of animal tissue - dispose of all necropsy waste using appropriate method as determined by the case-by-case risk analysis assessment.

\subsection{Brucella Testing Results}

Information was obtained from NOAA's Office of Protected Resources reporting results of animals tested for Brucella via polymerase chain reaction (PCR) or culture methods (Appendix A). All animals listed in Appendix A have tissues that are either currently stored in the Marine ESB or were received and shipped for analysis.

\subsection{Activities with Risk of Exposure}

\subsubsection{Receiving and Shipping Samples}

\section{Receiving Samples as a part of the Northern Gulf of Mexico Cetacean UME}

a.) Samples arrive via Fed Ex or UPS in coolers on dry ice or in shipping containers appropriate for frozen samples. Packages are shipped by personnel with current 49 CFR/ IATA Dangerous Goods Regulation Category 6 certificates. Hollings Marine Laboratory Shipping/Receiving will be notified the day before if possible about the arrival of a shipment. Only authorized personnel from the Marine ESB will pick up the coolers from Shipping/Receiving. If packages are in poor condition, leaking or labeled incorrectly the shipment will be refused and proper safety personnel notified. Packages are immediately transported via cart to the D104 ISO Class 6 anteroom.

b.) Frozen samples shipped to the Marine ESB for storage are packaged primarily as (Fig. 1) a) multiple tissues from one animal maintained within individually packaged and labeled (with tissue type and type of analysis) leak-proof plastic bags or vials and enclosed in one large leak-proof, evidence taped plastic bag; b) multiple tissues from one animal maintained within separately labeled (with analysis type) and evidenced taped leak-proof bag, enclosed within one large leak-proof plastic bag; and c) multiple samples from one animal maintained in cryovials within separate individually packaged, labeled and evidence taped leak-proof bag. Samples are removed from the cooler and placed in a precooled cart to maintain freezing temperatures while being inventoried. Standard PPE (disposable Tyvek coverall [full body], open-faced hood and 
mask or eyes-only hood, boot covers, safety glasses, and gloves [general laboratory vinyl gloves and/or cryogenic gloves]), and a fitted NIOSHcertified N-95 respirator are worn by all personnel involved in receiving samples. Marine ESB personnel open the sample bags and inventory contents relaying information to an ungloved second person writing down the contents in the Marine ESB log book or inventory form. This information is crossreferenced with the Chain of Custody forms at a later time.

c.) If samples must be repackaged due to bag breakage, the samples are placed on an absorbent paper lined cart and repackaged in a new labeled plastic bag. The cart is maintained in D104 labeled with a biohazard symbol and 'For use only with marine mammal samples from the Deepwater Horizon Oil Spill/Northern Gulf of Mexico UME Project'. The cart is decontaminated with $70 \%$ alcohol, or $10 \%$ bleach solution, after each use.

d.) Tissues are stored at $-80{ }^{\circ} \mathrm{C}$ in secured ultra-cold freezers. In addition, tissues that are stored in containers appropriate for $\mathrm{LN}_{2}$ storage (i.e., polytetrafluoroethylene [PTFE] jars and cryovials) will be stored in a secured $\mathrm{LN}_{2}$ vapor-phase $\left(-150^{\circ} \mathrm{C}\right)$ freezer: $\mathrm{LN}-\mathrm{AU}$.

\section{Receiving Samples for the National Marine Mammal Tissue Bank}

a.) Samples arrive via Fed Ex or UPS in biological dry shippers, labeled "Exempt Animal Specimen” and "Not restricted as per Special Provision A152”. Packages are immediately transported via cart to the D104 anteroom.

b.) Samples arrive as frozen whole tissues in fluorinated ethylene propylene (FEP) bags or PTFE jars, sealed and labeled. Samples are removed from the shipper and contents inventoried by relaying information to an ungloved second person writing down the contents in the Marine ESB log book or inventory form. Samples are then stored in either $\mathrm{LN}_{2}$ vapor-phase $\left(-150^{\circ} \mathrm{C}\right)$ or $-80^{\circ} \mathrm{C}$ freezers depending on space availability. Standard PPE is worn (disposable Tyvek coverall [full body], open-faced hood and mask or eyes-only hood, boot covers, safety glasses, and gloves [general laboratory vinyl gloves and/or cryogenic gloves]).

\section{Receiving Samples from other Collections}

a.) Samples arrive via Fed Ex or UPS in biological dry shippers labeled "Not restricted as per Provision A152”, coolers on dry ice, or in other shipping containers appropriate for frozen samples. Only authorized personnel from the Marine ESB pick up the shipping containers from Shipping/Receiving. If packages are in poor condition, leaking or labeled incorrectly the shipment will be refused and proper safety personnel notified. Packages are immediately transported via cart to the D104 anteroom.

b.) Samples arrive as frozen whole tissues or fluids in FEP bags, sealed and labeled, or in leak proof containers (i.e., PTFE jars, cryovials). Samples are removed from the shipping container inventoried by relaying information to an ungloved second person writing contents in the Marine ESB log book or 
inventory form. Samples are then stored in either $\mathrm{LN}_{2}$ vapor-phase $\left(-150^{\circ} \mathrm{C}\right)$ or $-80^{\circ} \mathrm{C}$ freezers depending on sample container and/or space availability. Standard PPE is worn (disposable Tyvek coverall [full body], open-faced hood and mask or eyes-only hood, boot covers, safety glasses, and gloves [general laboratory vinyl gloves and/or cryogenic gloves]). 
Figure 1. Frozen samples shipped to the Marine ESB for storage in multiple packaging.

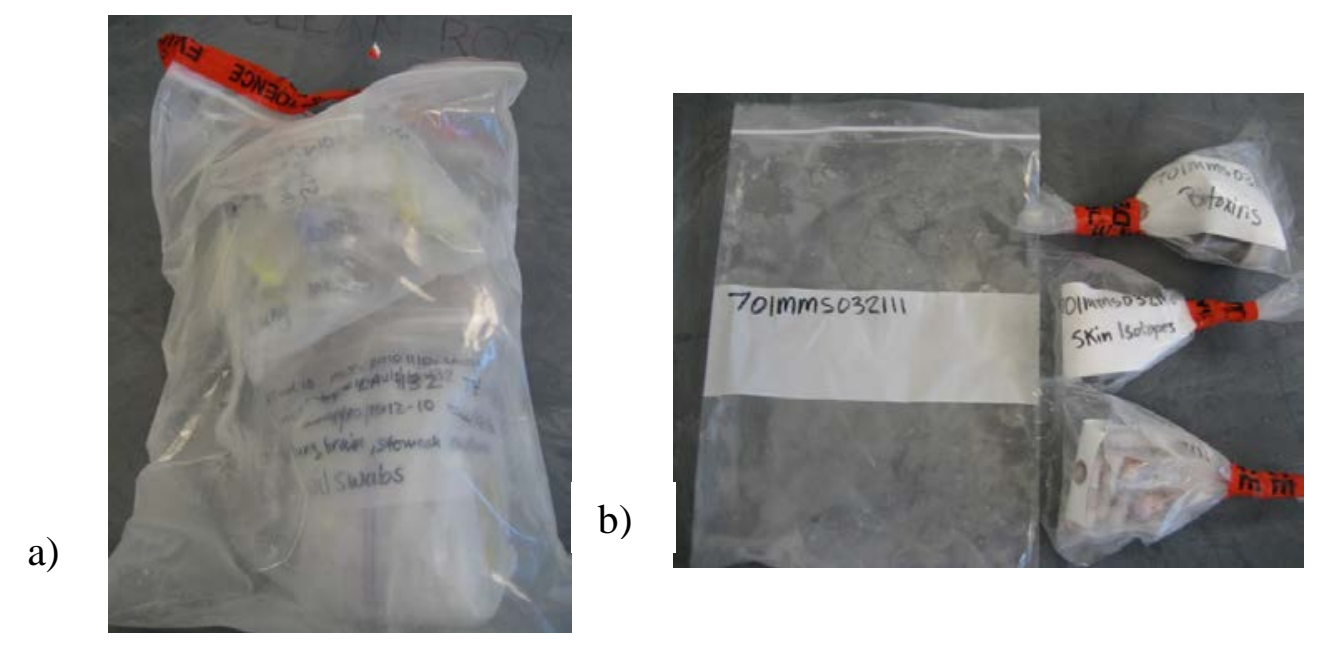

c)

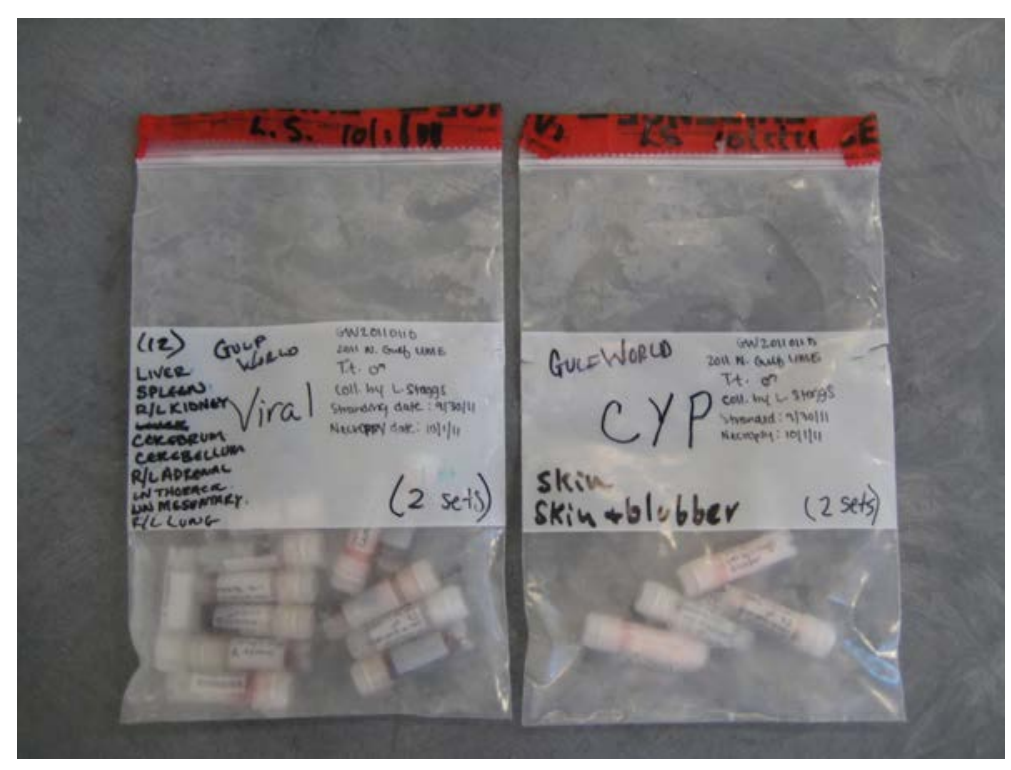




\subsubsection{Collection and Processing of Samples for NMMTB \\ Collection of Samples for NMMTB from Necropsy Site}

a.) Minimum PPE recommendations (MMHSRP Interim Brucella Guidelines [08August2012]) consist of disposable gloves, closed-toed disinfectable footwear, Tyvek frocks and safety glasses. Sample collection takes place under variable field conditions or in a laboratory. When samples are ready for collection Marine ESB personnel collect whole tissue samples in FEP bags, seal, and label the bags with zip ties.

b.) During procedures that create aerosols (Stryker saw, high pressure hose cleaning, rib cracking, etc.) respiratory protection in the form of a NIOSHcertified N-95 filtering respirator is recommended.

c.) When all tissues are collected they are transported to the Marine ESB either by hand or by automobile in rolling coolers with wet ice. Samples are stored in $\mathrm{LN}_{2}$ vapor-phase $\left(-150^{\circ} \mathrm{C}\right)$ or $-80^{\circ} \mathrm{C}$ freezers or immediately cataloged for archive.

d.) Gloves and Tyvek frocks must be disposed of before leaving the necropsy site. Footwear should be disinfected with either $70 \%$ alcohol or $10 \%$ bleach solution for 10 minutes before leaving necropsy site.

\section{Processing of Samples for NMMTB Archive and Clean Up of Supplies (12)}

a.) Standard PPE (disposable Tyvek coverall [full body], open-faced hood and mask or eyes-only hood, boot covers, safety glasses, and gloves [general laboratory vinyl gloves and/or cryogenic gloves]) is worn by all personnel when processing an animal that is known to have been collected from a subsistence harvest. If the origin of the animal is unknown or known to be collected from a stranded cetacean or pinniped standard PPE plus a fitted NIOSH-certified N-95 respirator is worn by all personnel during processing. Cut resistant gloves are also worn on the non-cutting hand of the personnel processing the sample.

b.) Samples are thawed on absorbent mats, removed from their bags and rinsed with water to remove any debris or ice crystals.

e.) Tissue is transferred to a cutting board covered with Bytac surface protector and a FEP sheet, two - 150 gram portions are cut from the whole tissue using a sharpened titanium knife and placed in clean PTFE jars. The jars are sealed and labeled then placed in long-term storage in $\mathrm{LN}_{2}$ vapor-phase $\left(-150^{\circ} \mathrm{C}\right)$ freezers.

c.) Knife handles are unscrewed from the blade taking great care to avoid cuts and all pieces are scrubbed with hot soapy water and rinsed. Cut-resistant gloves and water collection containers are washed thoroughly with hot water. Removable surfaces (Bytac and FEP sheeting), disposable PPE (Coveralls, hoods, masks, and boot covers) are disposed as regular trash. Excess tissue from chemically euthanized animals must be disposed of as biohazardous waste. Excess tissue from all other animals can be disposed as regular trash. 
d.) Surfaces are decontaminated using $70 \%$ isopropanol spray and wiping all surfaces of any visible splatters or tissue.

\subsubsection{Cryohomogenization of Archived Tissues}

\section{Cryohomogenization of Tissues from NMMTB and Other Projects (12)}

a.) Standard PPE (disposable Tyvek coverall [full body], open-faced hood and mask or eyes-only hood, boot covers, safety glasses, and gloves [general laboratory vinyl gloves and/or cryogenic gloves]) is worn when conducting cryohomogenization of an animal that is known to have been collected from a subsistence harvest. If the origin of the animal is unknown or known to be collected from a stranded cetacean or pinniped standard PPE plus a fitted NIOSH certified N-95 respirator is worn during homogenizations.

b.) All supplies needed are pre-cooled in a working $\mathrm{LN}_{2}$ vapor-phase $\left(-150^{\circ} \mathrm{C}\right)$ freezer (PTFE disk mill, smasher, spatula, scoop, labeled $15 \mathrm{~mL}$ jars, and stainless steel shaker plates) then transferred to a pre-cooled cryocart when needed (Figure 2). All work takes place in a MVE Cryocart unless otherwise stated.

c.) After locating the sample, it is removed from an archive $\mathrm{LN}_{2}$ freezer and placed in the cryocart. The sample lid is unscrewed and placed aside. An attempt is made to dislodge the sample from the jar directly into the interior of the smasher with puck removed by hitting the top of the inner ring with the jar overturned. If the sample remains in the jar it will be removed from the cryocart and placed in small FEP bag. The jar and bag will be laid flat on a cutting board covered in Bytac surface protector and an FEP sheet. A sledge hammer wrapped in Bytac and FEP sheeting is used to crack the frozen sample by hammering on the flat side of the jar through the FEP bag. Once the sample is cracked internally or the jar is cracked another attempt to dislodge the sample into the interior of the smasher will typically result in success.

d.) When the sample is removed from the jar into the smasher interior and the puck is replaced it is then brought under the compressed air fragmentation device. A $40.9 \mathrm{~kg}$ weight is dropped on the smasher from a height of 1 meter fracturing the tissue into smaller pieces. The smasher is placed in the cryocart. The puck and ring are removed and set aside.

e.) The lid of the PTFE disk mill is removed, material from the base of the smasher is scraped using the spatula into the disk mill and the lid is replaced. The disk mill is sandwiched between the two stainless steel plates and clamped into the TS-250 shaker. With the lid in place the shaker will vigorously shake the mill for up to 3 minutes pulverizing the contents into frozen powder. Some tissue leakage can occur.

f.) To mitigate potential aerosols from leakage that may have occurred milling, it is recommended to wait at least 5 seconds before opening the lid of the TS250 shaker. This time will allow particles to "settle" before the lid is opened slowly. 
g.) The disk mill is placed back in the cryocart. The lid, puck and ring are removed and the resulting tissue in powder form is scooped into jars and capped. Once completed the jars are weighed and weights recorded in the Specimen Bank notebook then jars are stored in an archive $\mathrm{LN}_{2}$ vapor-phase freezer.

h.) Immediate cleaning procedures include; wiping down the thawed stainless steel plates with a Tex-wipe and $70 \%$ isopropanol and placing them back in the working freezer for the next homogenization, rinsing the disk mill, smasher, spatula, and scoop with hot water for eventual chemical cleaning (12).

i.) The outside of the cryocart, balance, TS-250 Disk Mill Shaker, and surrounding floor of the working freezer and compressed air fragmentation device is decontaminated with $70 \%$ isopropanol. 
Figure 2. MVE Cryocart and homogenization set up.

a.)

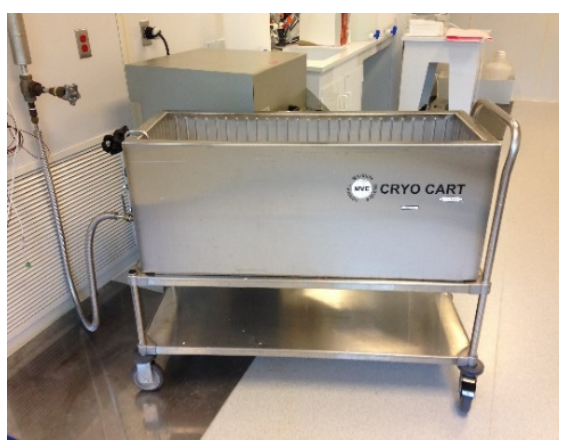

b.)

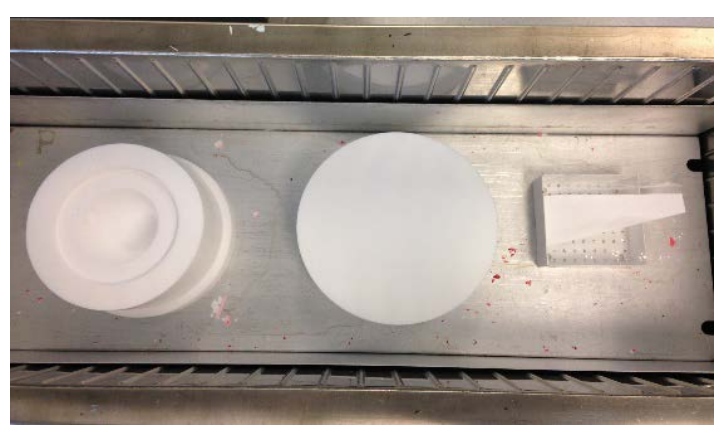

c.)

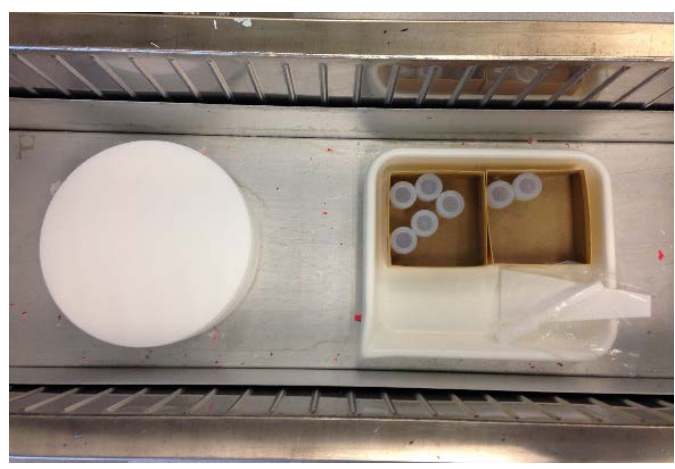




\subsection{Personnel Training and Expertise}

\subsubsection{Required trainings and certifications}

All personnel working with protocols covered by this risk assessment must be current with the following trainings:

NIST Marine ESB Introduction to Cleanrooms

NIST 710: Cryogen User Safety Training

NIST Fundamentals of Biosafety/ Bloodborne Pathogens/ Zoonoses

NIOSH N-95 Respirator Fit-Testing

IATA/DOT 49 CFR Dangerous Goods Shipping

IATA Dangerous Goods Division 6.2 Biological Substance Shipping

\subsubsection{Responsible Parties and Authorized Personnel}

Amanda Moors (NIST - Marine ESB Program Coordinator) is responsible for tracking that all personnel have been trained in the proper procedures and risks associated with work involving biological samples from marine animals with unknown pathogenicity and those that have tested or will test positive for marine Brucella or zoonotic pathogens. All personnel working with the Gulf of Mexico UME samples and present in the lab when work is underway will have appropriate BSL-2 training. Training rosters are maintained by NIST and are available upon request. All personnel will report immediately to the lab supervisor and the HML Safety Officer in the event of any laboratory incident. Personnel that are pregnant, or immunocompromised, should avoid working directly with samples from projects where Brucella is suspected.

To date, the following Marine ESB personnel have been or were involved in the handling of samples for storage purposes or shipping samples to laboratories for analysis: Paul Becker (NIST), Rebecca Pugh (NIST), Amanda Moors (NIST), Jennifer Ness (NIST), Melannie Bachman (NIST), Debra Ellisor (formerly Dakota Consulting, NIST), Jennifer Trevillian (formerly Dakota Consulting, NIST), Danielle Peterson (JHT, Inc.), Jody Rhoderick (Dakota Consulting), and Lauren Rust (SAIC). 


\subsection{Evaluate and Prioritize Risk}

Each task or activity in which specimen bank personnel can come into contact with a potential source of Brucella is evaluated to determine the hazard and the likelihood the hazard will occur. Table 1 outlines the hazard associated with each task by project.

Table 1. Exposure risk based on tasks or activities conducted with animal tissues in the Marine Environmental Specimen Bank.

Task or Activity

Exposure Risk

\begin{tabular}{|c|c|c|c|c|}
\hline & Hazard & Hazard Description & Likelihood & Risk \\
\hline \multicolumn{5}{|l|}{ Receiving and shipping samples } \\
\hline \multirow{2}{*}{ Northern Gulf of Mexico UME } & Direct contact & Open containers & Moderate & Low \\
\hline & Sharps & Broken glass & Moderate & High \\
\hline NMMTB & Direct Contact & Open containers & Unlikely & Low \\
\hline Other collections & Direct Contact & Open containers & Unlikely & Low \\
\hline \multicolumn{5}{|l|}{ Collection and processing } \\
\hline \multirow[t]{2}{*}{ Collection from necropsy } & Aerosols/Splash & $\begin{array}{l}\text { Manipulating the carcass and } \\
\text { tissues }\end{array}$ & Low & Low \\
\hline & Direct Contact & Spill through open container & Unlikely & Low \\
\hline \multirow[t]{4}{*}{ Processing for NMMTB archive } & Sharps & Cuts and knicks via knives & High & High \\
\hline & Direct Contact & $\begin{array}{l}\text { Through sleeves, paperwork, } \\
\text { surface contact }\end{array}$ & High & Moderate \\
\hline & Splash & $\begin{array}{l}\text { Cleaning tissues, splatters } \\
\text { during processing }\end{array}$ & High & Moderate \\
\hline & Sharps & Cuts while cleaning knives & Moderate & Moderate \\
\hline \multicolumn{5}{|l|}{ Cryohomogenization of tissues } \\
\hline \multirow[t]{4}{*}{ NMMTB } & Splatter/Splash & $\begin{array}{l}\text { Breaking jar and dislodging } \\
\text { tissue }\end{array}$ & Moderate & Moderate \\
\hline & Aerosols & $\begin{array}{l}\text { Leaking during milling, } \\
\text { manipulating frozen } \\
\text { powder with scoops and } \\
\text { spatula. }\end{array}$ & Moderate & Moderate \\
\hline & Direct Contact & Through surface contact & Moderate & Moderate \\
\hline & Splash & Cleaning mills in sink & Moderate & Moderate \\
\hline \multirow[t]{4}{*}{ Other projects } & Splatter/Splash & $\begin{array}{l}\text { Breaking jar and dislodging } \\
\text { tissue }\end{array}$ & Moderate & Low \\
\hline & Aerosols & $\begin{array}{l}\text { Leaking during milling, } \\
\text { manipulating frozen } \\
\text { powder with scoops and } \\
\text { spatula. }\end{array}$ & Moderate & Low \\
\hline & Direct Contact & Through surface contact & Moderate & Low \\
\hline & Splash & Cleaning mills in sink & Moderate & Low \\
\hline
\end{tabular}

2.6 Develop or evaluate controls to mitigate exposure

Engineering controls and workplace practices provide the primary barrier to injury or exposure while PPE provides secondary protection. Table 2 outlines the engineering and workplace controls in place to mitigate hazards related to potential Brucella exposure for tasks and activities in the Marine ESB. 
Table 2. Hazards and recommended controls to reduce laboratory worker exposure to Brucella.

\begin{tabular}{|c|c|c|c|}
\hline \multirow[t]{2}{*}{ Task or Activity } & \multicolumn{3}{|c|}{ Hazards and Recommended Controls } \\
\hline & Hazard & $\begin{array}{l}\text { Engineering Controls or Workplace } \\
\text { Practices }\end{array}$ & PPE \\
\hline \multicolumn{4}{|c|}{ Receiving and shipping samples } \\
\hline \multirow[t]{2}{*}{$\begin{array}{l}\text { Northern Gulf } \\
\text { of Mexico } \\
\text { UME }\end{array}$} & Direct contact & $\begin{array}{l}\text { Absorbent paper on benchtop and disinfection } \\
\text { of all work surfaces using } 10 \% \text { bleach } \\
\text { solution. }\end{array}$ & $\begin{array}{l}\text { Standard PPE* plus } \\
\text { N-95 respirator }\end{array}$ \\
\hline & Sharps & $\begin{array}{l}\text { Place broken glass in available sharps container } \\
\text { and dispose as hazardous biological waste. }\end{array}$ & \\
\hline NMMTB & Direct Contact & None & Standard PPE* \\
\hline $\begin{array}{l}\text { Other } \\
\text { collections }\end{array}$ & Direct Contact & None & Standard PPE* \\
\hline \multicolumn{4}{|c|}{ Collection and processing } \\
\hline $\begin{array}{c}\text { Collection from } \\
\text { necropsy site }\end{array}$ & Direct Contact & $\begin{array}{l}\text { Personnel will not participate in active removal } \\
\text { of tissues. Tissues are placed in clean FEP } \\
\text { bag and sealed using a zip tie with a label } \\
\text { then placed in a cooler on ice for transport. }\end{array}$ & $\begin{array}{l}\text { Disposable field } \\
\text { frock, washable } \\
\text { shoes, Gloves, and } \\
\text { N-95 respirator. }\end{array}$ \\
\hline \multirow[t]{3}{*}{$\begin{array}{l}\text { Processing for } \\
\text { NMMTB } \\
\text { archive }\end{array}$} & Direct Contact & $\begin{array}{l}\text { Processor will not handle paperwork. Suits are } \\
\text { discarded after processing. Excess tissue is } \\
\text { discarded. }\end{array}$ & $\begin{array}{l}\text { Standard } \mathrm{PPE}^{*}, \mathrm{~N}- \\
95 \text { respirator } \\
\text { unless subsistence }\end{array}$ \\
\hline & Splash & $\begin{array}{l}\text { Cleaning takes place in high sided bin, users } \\
\text { are careful to minimize splashing/splatters. }\end{array}$ & $\begin{array}{l}\text { hunted animal, } \\
\text { cut-resistant glove }\end{array}$ \\
\hline & Sharps & $\begin{array}{l}\text { When taken apart the metal knife should be } \\
\text { placed in a plastic container and washed with } \\
\text { a brush. Do not use fingers to loosen screws. }\end{array}$ & $\begin{array}{l}\text { on non-cutting } \\
\text { hand. }\end{array}$ \\
\hline \multicolumn{4}{|c|}{ Cryohomogenization of tissues } \\
\hline \multirow[t]{4}{*}{ NMMTB } & Splatter/Splash & $\begin{array}{l}\text { FEP bags are placed over the open end of the } \\
\text { jar before attempting to crack open. } \\
\text { Dislodging is done inside a freezer typically } \\
\text { arm's length away from the face. }\end{array}$ & $\begin{array}{l}\text { Standard } \mathrm{PPE}^{*}, \mathrm{~N}- \\
95 \text { respirator } \\
\text { unless subsistence } \\
\text { animal }\end{array}$ \\
\hline & Aerosols & $\begin{array}{l}\text { Mill is tightly closed using the shaker's lever; a } \\
\text { lid is used to minimize risk from moving } \\
\text { parts and possibly aerosols. Wait at least } 5 \\
\text { seconds before opening the lid to allow for } \\
\text { particles to "settle.” }\end{array}$ & \\
\hline & Direct Contact & None & \\
\hline & Splash & $\begin{array}{l}\text { Water will not be turned on directly on top of } \\
\text { mill to minimize splashing. }\end{array}$ & \\
\hline \multirow[t]{4}{*}{ Other projects } & Splatter/Splash & $\begin{array}{l}\text { FEP bags are placed over the open end of the } \\
\text { jar before attempting to crack open. } \\
\text { Dislodging is done inside a freezer typically } \\
\text { arm's length away from the face. }\end{array}$ & Standard PPE* \\
\hline & Aerosols & $\begin{array}{l}\text { Mill is tightly closed using the shaker's lever; a } \\
\text { lid is used to minimize risk from moving } \\
\text { parts and possible aerosols. }\end{array}$ & \\
\hline & Direct Contact & None & \\
\hline & Splash & $\begin{array}{l}\text { Water will not be turned on directly on top of } \\
\text { mill to minimize splashing. }\end{array}$ & \\
\hline
\end{tabular}

* Standard PPE (disposable Tyvek coverall [full body], open-faced hood and mask or eyes-only hood, boot covers, safety glasses, and gloves [general laboratory vinyl gloves and/or cryogenic gloves]). 


\section{Emergency Procedures}

In the event of an injury or accident

- Call 9-911 (if needed), treat the injured, and prevent further injury/damages

- Collect information on the incident including who, what, when, where, why, and how, and if applicable, gather information from witnesses and others involved in the incident.

- Notify your supervisor or the lab lead (or if unreachable, any supervisor) and the NOAA HML Safety office as soon as possible.

In the event of a spill

- Alert people in the area.

- Cover an area twice the size of the spill with disinfectant soaked-paper towels.

- Wipe down any contaminated stationary equipment or furniture with disinfectant.

- Use forceps, tongs, or broom to remove broken glass and other items; place in sharps container or red bag.

- Remove towels and re-clean area with disinfectant solution.

- Disposable items used are to be put in the biohazard bag for incineration

- Reusable clean-up items and other reusable equipment are to be decontaminated using chemical treatment.

\section{References}

1. Pugh RS, et al. (2008) Design and applications of the National Institute of Standards and Technology's (NIST's) environmental specimen banking programs. Cell Preservation Technology 6(1):59-72.

2. Venn-Watson S, et al. (2015) Adrenal Gland and Lung Lesions in Gulf of Mexico Common Bottlenose Dolphins (Tursiops truncatus) Found Dead following the Deepwater Horizon Oil Spill. Plos One 10(5):23.

3. Pugh RS, et al. (2006) The National Marine Mammal Tissue Bank Specimen Inventory. (National Institute of Standards and Technology), pp 1-545.

4. Sohn AH, et al. (2003) Human neurobrucellosis with intracerebral granuloma caused by a marine mammal Brucella spp. Emerging Infectious Diseases 9(4):485-488.

5. McDonald WL, et al. (2006) Characterization of a Brucella sp strain as a marinemammal type despite isolation from a patient with spinal osteomyelitis in New Zealand. Journal of Clinical Microbiology 44(12):4363-4370.

6. Brew SD, Perrett LL, Stack JA, MacMillan AP, \& Staunton NJ (1999) Human exposure to Brucella recovered from a sea mammal. Veterinary Record 144(17):483-483.

7. Anonymous (2011) Select agents and toxins list, CDC/APHIS (Registry NSA).

8. Anonymous (2001) Brucella spp. [MSDS Online], Public Health Agency of Canada (Security OoL).

9. $\quad$ Medicine ISUCoV (July 2009) Brucellosis in Marine Mammals.

10. Huddleson IF \& Munger M (1940) A Study of an Epidemic of Brucellosis Due to Brucella melitensis*. American Journal of Public Health and the Nations Health 30(8):944-954. 
11. Staszkiewicz J, Lewis C, Colville J, Zervos M, \& Band J (1991) Outbreak of Brucella melitensis among microbiology laboratory workers in a community hospital. Journal of clinical microbiology 29(2):287-290.

12. Pugh RS, Ellisor MB, Moors AJ, Porter BJ, \& Becker PR (2007) Marine Environmental Specimen Bank: Clean Room and Specimen Bank Protocols. in NISTIR (National Institute of Standards and Technology). 


\section{Appendix A.}

Animals with tissues archived in the Marine ESB that have tested positive for Brucella from the Deep Water Horizon (DWH) Gulf of Mexico UME. Testing was conducted using polymerase chain reaction (PCR) based assays and confirmed with culture assays. Tissues archived, may or may not include the tissue tested for Brucella. Tissues archived presently or in the past and their quantities are listed along with the earliest receipt date for any tissue from that animal including the present or past freezer locations. Lung LN (Lung associated lymph node), CSF (cerebrospinal fluid)

\begin{tabular}{|c|c|c|c|c|}
\hline DWH Gulf of Mexico UME & & $\begin{array}{c}\text { Test } \\
\text { Result }\end{array}$ & Tissues in Marine ESB & \\
\hline Field Number & Tissue Tested & $\begin{array}{l}\text { PCR / } \\
\text { Culture }\end{array}$ & Tissues Archived (quantity) & $\begin{array}{l}\text { Earliest Date } \\
\text { Received }\end{array}$ \\
\hline 01IMMS011313 & $\begin{array}{l}\text { Lung } \\
\text { Lung LN }\end{array}$ & $\begin{array}{c}+/+ \\
- \\
\end{array}$ & Skin/Blubber (3) & 17 Jul 2013 \\
\hline 07DISL030413 & $\begin{array}{l}\text { Lung } \\
\text { Lung LN }\end{array}$ & $\begin{array}{l}+/+ \\
+/+\end{array}$ & $\begin{array}{l}\text { Brain, Lung LN (2), Lung, Spleen, Kidney, Liver, } \\
\text { Skin/Blubber }\end{array}$ & $17 \mathrm{Jul} 2013$ \\
\hline 09DISL030612 & Lung & $+/+$ & Skin/Blubber, Liver, Lung, Spleen, Kidney, Skin & 17 Jul 2013 \\
\hline 09IMMS022812 & Lung & $+/+$ & $\begin{array}{l}\text { (Lung, Spleen, Kidney, Liver, Adrenal Gland, Cerebrum, } \\
\text { Cerebellum, Brain Stem, Thoracic Fluid, Mesenteric LN) (3) } \\
\text { Skin/Blubber, Liver in glass, Lung in glass, Urine in glass }\end{array}$ & 18 Sept 2012 \\
\hline 23IMMS031713 & Lung & $+/+$ & Skin/Blubber (6) & 17 Jul 2013 \\
\hline 29IMMS033113 & Lung & $+1+$ & Skin/Blubber (3), (Lung, Spleen, Kidney, Liver) (3) & 17 Jul 2013 \\
\hline 36IMMS042213 & Lung & $+/+$ & Skin/Blubber (3) & $17 \mathrm{Jul} 2013$ \\
\hline 39IMMS042713 & $\begin{array}{l}\text { Lung LN } \\
\text { Lung } \\
\text { Spinal Cord } \\
\text { Brain }\end{array}$ & $\begin{array}{c}+1+ \\
- \\
- \\
-\end{array}$ & $\begin{array}{l}\text { Skin/Blubber (3), Brain, Lung, (Viral: Lung, Spleen, Kidney, } \\
\text { Liver, Lung LN, Brain, Adrenal Gland) (3), Skin, Brucella - } \\
\text { PCR: CSF, Lungworms, Testicle, Pulmonary LN, Mesenteric } \\
\text { LN }\end{array}$ & 17 Jul 2013 \\
\hline 58IMMS031211 & Lung & $+/+$ & Swab (4), Skin (5), Brain (12), Lung (3) & 28 Apr 2011 \\
\hline CDD-20110916-LA002 & $\begin{array}{l}\text { Lung LN } \\
\text { Lung } \\
\text { Brain }\end{array}$ & $\begin{array}{l}+/+ \\
+/+ \\
-\end{array}$ & $\begin{array}{l}\text { Brain (2), Lung (2), Lung LN (2), Spleen, Adrenal Gland, } \\
\text { Kidney, Liver, Dry Tissue }\end{array}$ & 17 Jul 2013 \\
\hline DCA-20130619-LA001 & $\begin{array}{l}\text { Lung LN } \\
\text { Lung } \\
\text { Brain }\end{array}$ & $\begin{array}{l}+/+ \\
+/+ \\
-\end{array}$ & $\begin{array}{l}\text { Skin/Blubber (2), Brain (3), Lung (2), Spleen (2), Adrenal } \\
\text { Gland (2), Kidney (2), Liver(2) }\end{array}$ & 9 Dec 2014 \\
\hline DCA-20130924-LA001 & $\begin{array}{l}\text { Spinal Cord } \\
\text { Lung } \\
\text { Lung LN } \\
\text { Brain }\end{array}$ & $\begin{array}{c}+/+ \\
- \\
- \\
-\end{array}$ & $\begin{array}{l}\text { Skin/Blubber (2), Brain (3), Lung LN (2), Lung (2), Spleen } \\
\text { (2), Adrenal Gland (2), Kidney (2), Liver (2), CSF (2), } \\
\text { Amniotic Fluid (2), Placenta (2), Umbilical Cord (2), Uterine } \\
\text { Horn (2), Lungworm, Mesenteric LN }\end{array}$ & 9 Dec 2014 \\
\hline
\end{tabular}




\begin{tabular}{|c|c|c|c|c|}
\hline $\begin{array}{l}\text { LFH-20120131- } \\
\text { LA001/Y12 }\end{array}$ & $\begin{array}{l}\text { Brain Stem/ } \\
\text { Spinal Cord } \\
\text { Lung } \\
\text { Lung LN } \\
\text { Lung Abscess } \\
\text { Lung }\end{array}$ & $\begin{array}{l}- \\
- \\
- \\
-\end{array}$ & Cerebellum (2), Brain Ventricle (2) & 18 Sept 2012 \\
\hline 01DISL012413 & Lung & + & Lung (3), Brain (2), Skin/Blubber & 17 Jul 2013 \\
\hline 02IMMS010912 & $\begin{array}{l}\text { Brainstem } \\
\text { caseous material } \\
\text { Whole Blood } \\
\text { Blowhole Swab } \\
\text { Feces } \\
\text { Brainstem } \\
\text { Ventral Brain } \\
\text { Lung } \\
\text { Lung LN }\end{array}$ & $\begin{array}{l}-1+ \\
- \\
- \\
- \\
- \\
- \\
- \\
-\end{array}$ & $\begin{array}{l}\text { (Viral: Lung, Spleen, Kidney, Liver, Adrenal Gland, } \\
\text { Cerebrum, Cerebellum, Brain Stem, Prescapular LN (2)) (3), } \\
\text { Serum (4), Skin, Skin/Blubber, Liver, Lung (2), Urine (2), } \\
\text { Bone Marrow, Genital LN, Abdominal Fluid, Testicle }\end{array}$ & 18 Sept 2012 \\
\hline 05 DISL022413 & Lung & + & $\begin{array}{l}\text { Brain (3), Lung, Spleen, Adrenal Gland, Kidney, Liver, } \\
\text { Skin/Blubber, Spinal Cord (2) }\end{array}$ & $17 \mathrm{Jul} 2013$ \\
\hline 05IMMS012712 & Lung & + & Skin/Blubber & $17 \mathrm{Jul} 2013$ \\
\hline 06IMMS030214 & $\begin{array}{l}\text { Amniotic Fluid } \\
\text { Brain } \\
\text { Fetal Tissue } \\
\text { Uterus }\end{array}$ & $\begin{array}{l}+ \\
- \\
- \\
-\end{array}$ & $\begin{array}{l}\text { Brain (4), Lung LN(3), Lung (4), Spleen (3), Adrenal Gland } \\
\text { (3), Kidney (3), Liver (3), Skin/Blubber (3), Uterus, } \\
\text { Pulmonary LN, Mesenteric LN, Amniotic Fluid (2), } \\
\text { Umbilical Cord, Brainstem/Spinal Cord, Placenta (2) }\end{array}$ & 9 Dec 2014 \\
\hline 08IMMS012913 & Lung & + & Skin/Blubber (3) & 17 Jul 2013 \\
\hline 08IMMS030210 & Lung & + & $\begin{array}{l}\text { Skin, Lung, Stomach, Spleen, Intestines, Heart, Blubber (2), } \\
\text { Muscle, Kidney }\end{array}$ & 28 Apr 2011 \\
\hline 12IMMS020813 & Lung & + & Skin/Blubber (3) & 17 Jul 2013 \\
\hline 13IMMS021013 & Lung & + & Skin/Blubber (3) & 17 Jul 2013 \\
\hline 14IMMS031012 & Lung & + & Skin/Blubber & 17 Jul 2013 \\
\hline 20IMMS031613 & $\begin{array}{l}\text { Lung } \\
\text { Lung LN }\end{array}$ & $\begin{array}{l}+ \\
+\end{array}$ & Skin/Blubber (3) & $17 \mathrm{Jul} 2013$ \\
\hline 24IMMS031912 & Lung & + & Skin/Blubber & 17 Jul 2013 \\
\hline 32IMMS022311 & Lung & + & Blubber (2), Lung (2), Liver (2), Mixed Frozen Tissues, RNA & 28 Apr 2011 \\
\hline 35IMMS041813 & $\begin{array}{l}\text { Testicle } \\
\text { CSF } \\
\text { Brain }\end{array}$ & $\begin{array}{l}+ \\
+ \\
+ \\
+\end{array}$ & $\begin{array}{l}\text { (Viral: Brain, Lung LN, Lung, Spleen, Adrenal Gland, } \\
\text { Kidney, Liver) (3), Lungworms, Brainstem/spinal Cord, } \\
\text { Pulmonary LN, Mesenteric LN }\end{array}$ & 17 Jul 2013 \\
\hline
\end{tabular}




\begin{tabular}{|c|c|c|c|c|}
\hline & Lung & - & & \\
\hline 38IMMS022611 & Lung & + & Swab (3), Blubber (4), Liver (5), Lung (4), RNA Extract & 28 Apr 2011 \\
\hline \multirow[t]{8}{*}{ 40IMMS102612 } & Genital LN & + & Cerebrum, Cerebellum, Brain Stem, Lung (2), Spleen, & 17 Jul 2013 \\
\hline & Amniotic Fluid & + & Adrenal Gland, Kidney, Liver, Genital LN, Amniotic Fluid, & \\
\hline & Umbilicus & + & Placenta, Uterus, Skin/Blubber, Brain, & \\
\hline & Fetus & - & & \\
\hline & Lung & - & & \\
\hline & Brain & - & & \\
\hline & Spinal Cord & - & & \\
\hline & Bone Marrow & - & & \\
\hline \multirow[t]{3}{*}{ 40IMMS042713 } & Uterus & + & Skin/Blubber (3), (Viral: Lung, Spleen, Kidney, Liver, Lung & 17 Jul 2013 \\
\hline & CSF & + & LN, Brain, Adrenal Gland) (3), Brain (2), Lung, Lungworms, & \\
\hline & Lung & + & Brainstem, Pulmonary LN, Mesenteric LN & \\
\hline 51IMMS030711 & Lung & + & $\begin{array}{l}\text { Guaze Swab, Skin (4), Blubber (5), Lung (5), Frozen Tissues, } \\
\text { Skull, RNA Extract }\end{array}$ & 28 Apr 2011 \\
\hline 62IMMS031511 & Lung & + & $\begin{array}{l}\text { Mixed Tissue Samples, Swabs (3), Meconium, Skin, Adrenal } \\
\text { Gland (4), Lung (4), Brain (12) }\end{array}$ & 28 Apr 2011 \\
\hline \multirow[t]{2}{*}{ 65IMMS031711 } & Lung & + & Mixed Frozen Samples, Whole Stomach, Blubber (4), Lung & 28 Apr 2011 \\
\hline & Lung LN & + & $\begin{array}{l}\text { (5), Kidney (3), Liver (5), Aqueous Humor (2) Swab (3), } \\
\text { Feces (2), Spleen, Lung LN (2), RNA Extracts }\end{array}$ & \\
\hline 66IMMS031811 & Lung & + & $\begin{array}{l}\text { Swabs (4), Skin (3), Skin Lesion (6), Pulmonary LN (5), } \\
\text { Liver (10), Adrenal Gland (5), Spleen (5), Thymus (4), Lung } \\
\text { (4), Kidney (4), Blubber (5), Feces (5), Small Intestine, Brain, } \\
\text { Cerebrum, Cerebellum, Midbrain }\end{array}$ & 28 Apr 2011 \\
\hline 70IMMS032111 & Lung & + & $\begin{array}{l}\text { Swab (2), Skin (3), Brain (4), Adrenal Gland (4), Liver (5), } \\
\text { Spleen (4), Lung (4), Meconium }\end{array}$ & 28 Apr 2011 \\
\hline 77IMMS032811 & Lung & + & $\begin{array}{l}\text { Brain (12), Spleen (4), Adrenal Gland (4) Liver (5), Lung (4), } \\
\text { Skin, Brain Swab, Meconium }\end{array}$ & 22 Jul 2011 \\
\hline \multirow[t]{2}{*}{ BP-2010-LA-168 } & Spinal Cord & + & Gauze Swab (2), Skin, Plasma (3), Serum (40), Blood (2), & 16 Nov 2010 \\
\hline & Lung & - & $\begin{array}{l}\text { Liver (2), Lung (2), Blubber (2), Urine (2), RNA Extract, } \\
\text { Spinal Cord }\end{array}$ & \\
\hline \multirow[t]{3}{*}{ CCC-20120117-LA001 } & Lung & + & Spleen (2), Kidney (2), Brain (2), Adrenal Gland (2), Lung & 18 Sept 2012 \\
\hline & Lung LN & + & LN (2), Lung (3), Liver (3), Skin/Blubber, Urine in glass & \\
\hline & Brain & - & & \\
\hline CES-20110218-LA001 & Lung & + & & 22 Mar 2011 \\
\hline
\end{tabular}




\begin{tabular}{|c|c|c|c|c|}
\hline & Skin & - & $\begin{array}{l}\text { Skin, Stomach, Kidney (2), Liver (2), Lung (2), Spleen (2), } \\
\text { Trachea, Brain (3), Mesenteric LN, Lung LN (2), Blubber (2), } \\
\text { Muscle, Feces, Umbilicus, RNA Extracts (4) }\end{array}$ & \\
\hline JSH-20130318-LA002 & $\begin{array}{l}\text { Lung } \\
\text { Brain Stem }\end{array}$ & $\begin{array}{l}++ \\
+\end{array}$ & $\begin{array}{l}\text { Skin/Blubber (2), Lung (2), Brain, Adrenal Gland, Kidney, } \\
\text { Liver }\end{array}$ & 17 Jul 2013 \\
\hline JSH-20130404-LA001 & Lung & + & $\begin{array}{l}\text { Skin/Blubber, Lung (2), Adrenal Gland, Spleen, Kidney, } \\
\text { Brain (5), Liver }\end{array}$ & 17 Jul 2013 \\
\hline JSH-20130417-LA001 & $\begin{array}{l}\text { Spinal Cord } \\
\text { Testicle } \\
\text { Lung }\end{array}$ & $\begin{array}{l}+ \\
- \\
-\end{array}$ & $\begin{array}{l}\text { Skin/Blubber (2), Brain (4), Kidney, Liver (2), Lung LN, } \\
\text { Lung (3), Spleen, Adrenal Gland, Lungworms, Skin Lesion } \\
\text { (3), Spinal Cord, Pulmonary LN, Spinal Cord, Skin Lesions } \\
\text { (3), Testes }\end{array}$ & 17 Jul 2013 \\
\hline JSH-20130429-LA001 & Lung & + & Skin/Blubber, Lung, Skin, Blubber (2) & 23 Sept 2014 \\
\hline MCT-20101203-LA001 & Lung & + & $\begin{array}{l}\text { Mixed Frozen Tissues, Culturette of Lung, Liver, Spleen, } \\
\text { Kidney, Feces }\end{array}$ & 18 Mar 2011 \\
\hline MCT-20110228-LA001 & $\begin{array}{l}\text { Pulmonary LN } \\
\text { CSF } \\
\text { Lung }\end{array}$ & $\begin{array}{l}+ \\
+ \\
-\end{array}$ & $\begin{array}{l}\text { Kidney, Lung (2), Liver, Leeches, Blubber (2), Muscle, CSF, } \\
\text { Urine, Blood, Bile, Stomach, Stomach Contents, Peritoneal } \\
\text { Fluid, Mid Peduncle Granuloma, Spleen, Trachea, } \\
\text { Mesenteric LN, Pulmonary LN (2), Cervical LN, Skin, } \\
\text { Otoliths, RNA Extract (4) }\end{array}$ & 11 Mar 2011 \\
\hline MCT-20110321-LA001 & Lung & + & Blubber & 18 Dec 2014 \\
\hline MRB-20110315-LA001 & $\begin{array}{l}\text { Lung } \\
\text { Lung LN }\end{array}$ & $\begin{array}{c}+/+ \\
+\end{array}$ & $\begin{array}{l}\text { Mixed Tissue Samples, Whole Stomach, Skin, Skin/Blubber, } \\
\text { RNA Extract (3) }\end{array}$ & 18 Mar 2011 \\
\hline MSB-20110501-LA001 & $\begin{array}{l}\text { Lung } \\
\text { Lung LN } \\
\text { Brain }\end{array}$ & $\begin{array}{l}+ \\
- \\
-\end{array}$ & $\begin{array}{l}\text { Brain (2), Lung LN (2), Lung (2), Spleen, Adrenal Gland, } \\
\text { Kidney, Liver, Skin/Blubber }\end{array}$ & 17 Jul 2013 \\
\hline $\begin{array}{l}\text { RIB-20110111- } \\
\text { LA002/LA441 }\end{array}$ & Lung & + & $\begin{array}{l}\text { Swabs (3), Liver, Kidney, Muscle, Stomach Contents, } \\
\text { Blubber, Lung (3), Feces, Urine, Blood, Intestine, Mixed } \\
\text { Frozen Samples, RNA Extract }\end{array}$ & 18 Mar 2011 \\
\hline
\end{tabular}

